\title{
Fine Structure of Marteilia sydneyi sp. n.: Haplosporidan Pathogen of Australian Oysters
}

\section{Frank O. Perkins}

Virginia Institute of Marine Science

Peter H. Wolf

Follow this and additional works at: https://scholarworks.wm.edu/vimsarticles

Part of the Marine Biology Commons

\section{Recommended Citation}

Perkins, Frank O. and Wolf, Peter H., Fine Structure of Marteilia sydneyi sp. n.: Haplosporidan Pathogen of Australian Oysters (1976). Journal of Parsitology, 62(4), 528-538.

https://scholarworks.wm.edu/vimsarticles/1990 


\title{
FINE STRUCTURE OF MARTEILIA SYDNEYI SP. N.- HAPLOSPORIDAN PATHOGEN OF AUSTRALIAN OYSTERS*
}

\author{
Frank O. Perkins and Peter H. Wolf \\ Virginia Institute of Marine Science, Gloucester Point, Virginia 23062 and Fisheries Branch, Chief \\ Secretary's Department, Sydney Australia
}

\begin{abstract}
A new species of oyster pathogen, Marteilia sydneyi, from Australian oysters, Crassostrea commercialis, is described incorporating light and electron microscope observations. The pathogen is a haplosporidan which exists as a plasmodium in the oyster hepatopancreas. Upon sporulation, 8 to 16 uninucleate sporangial primordia are internally cleaved (endogenously budded) from each plasmodium; thus conversion to a sporangiosorus occurs. Each sporangium enlarges and internally cleaves into 2 or 3 spore primordia each of which, in turn, internally cleaves into 3 uninucleate sporoplasms of graded sizes, the largest containing the smaller 2 in a vacuole and the intermediate-sized one containing the smallest in a vacuole. The spore wall is continuous without an orifice or operculum.
\end{abstract}

Wolf (1972) recorded the presence of a haplosporidan in Sydney Rock oysters (Crassostrea commercialis Iredale and Roughley) from Moreton Bay, Queensland, Australia, in which he noted spores in the hepatopancreas. In subsequent papers Grizel et al. (1974) and Mix and Sprague (1974) noted its close similarity to Marteilia refringens Grizel, Comps, Bonami, Cousserans, Duthoit, and LePennec, a pathogen of Ostrea edulis Linné in French estuaries. Grizel et al. (1974) suggested that $M$. refringens is one of the lower fungi; however, Perkins (1976) noted haplosporidan characteristics in the form of haplosporosomes and in the mechanism of spore formation from sporangia. The organism has, therefore, been placed in the Class Haplosporea. The present paper shows that the pathogen of $C$. commercialis is a haplosporidan and is in the same genus as the pathogen of Ostrea edulis, popularly known as the agent of Aber disease (Alderman, 1974).

The pathogen has been found only in subtropical and tropical regions of the eastern

Received for publication 14 October 1975.

* Contribution No. 744, Virginia Institute of Marine Science, Gloucester Point, Virginia 23062.
Australian coast, not in the colder waters south of Richmond River in Australia. The other species of Crassostrea, C. echinata Quoy and Gaimard, from the eastern coast of Australia is also parasitized by a species of Marteilia probably identical to the one described herein (Wolf, unpublished).

\section{MATERIALS AND METHODS}

Blocks of hepatopancreas, 1 to $4 \mathrm{~mm}^{3}$ in size, were obtained from Moreton Bay, Queensland oysters (C. commercialis) and fixed in 6\% glutaraldehyde for 5 to 7 days during transit from Australia to the U.S.A. Subsequent treatment has been described (Perkins, 1976). Light micrographs were obtained from histological slides of oysters fixed in Davidson's fluid and stained with Harris' hematoxylin and eosin.

Conclusions concerning spore structure were based on electron microscope observations of serial sections through 2 spores as well as observations of individual sections. Serial sections were mounted on a Formvar substrate on Mason and Morton slot $(2 \times 1 \mathrm{~mm})$ discs.

\section{RESULTS}

Marteilia sydneyi sp. $\mathrm{n}$.

(Figs. 1-11)

Host: Crassostrea commercialis Iredale and Roughley.

Locality: Moreton Bay, Queensland, Australia.

Habitat: Hepatopancreas.

Figunes 1-11. Marteilia sydneyi sp. n., pathogen of the Australian oyster, Crassostrea commercialis. All Figs. are electron micrographs unless otherwise indicated. 1. Light micrograph of hematoxylin and eosin-stained plasmodium in oyster hepatopancreas. Plasmodial nuclei (N); oyster nucleus (O). $\times 2,000$. 2. Plasmodial mitochondrion. Crista (C). $\times 103,000.3$. Multivesicular body of plasmodium. Haplosporosomes $(\mathrm{H})$ are believed to arise from vesicles $(\mathrm{V})$ in multivesicular body. $\times 100,000.4$. Plasmodial haplosporosomes. Note internal membrane (arrow) and delimiting membrane (double arrow) of each organelle. $\times 154,000$. 

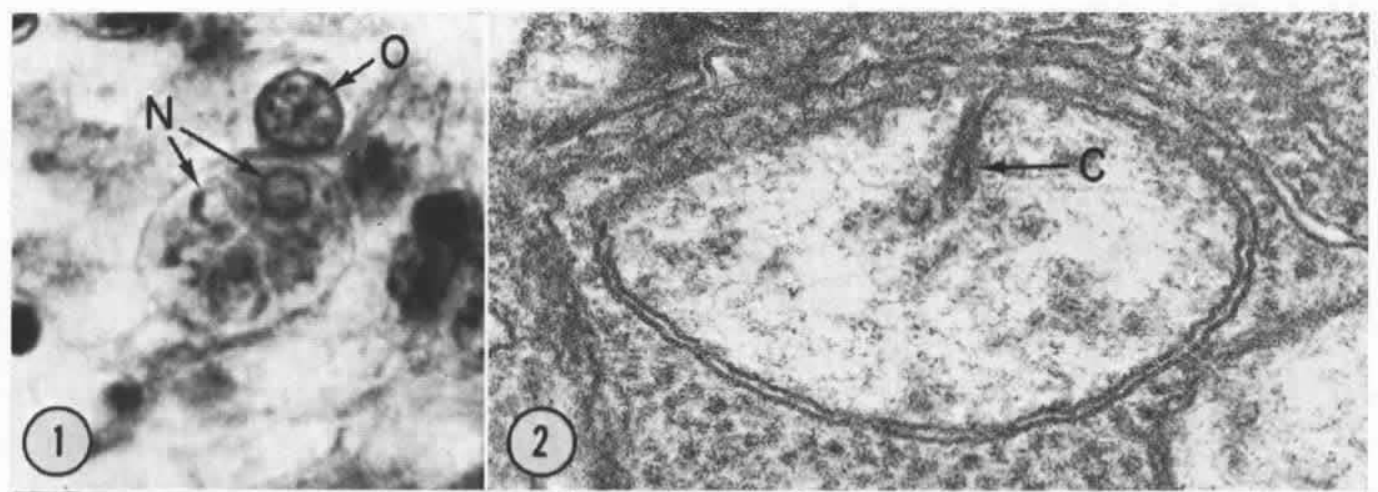

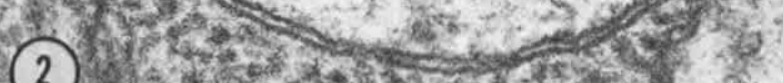

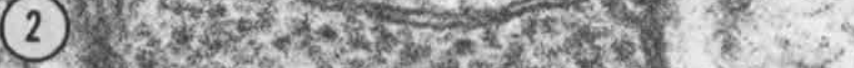

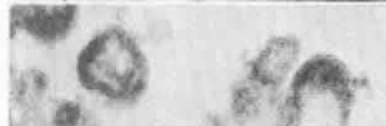

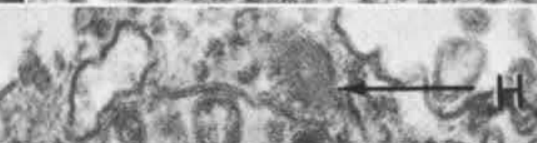

Howe

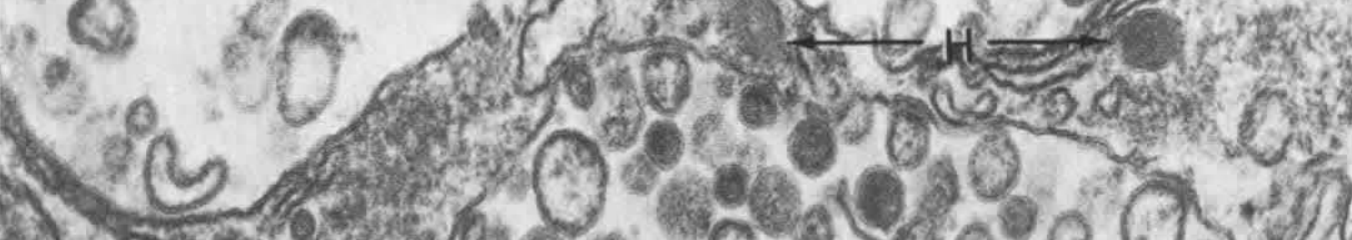

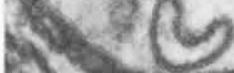

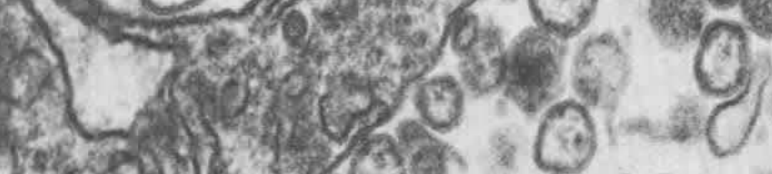

(x)

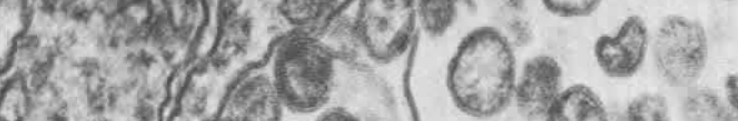

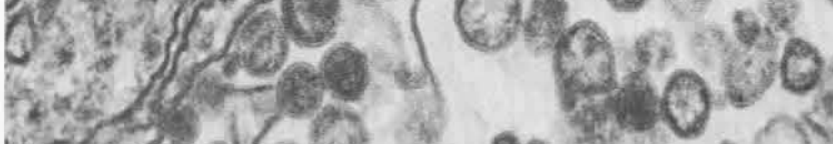

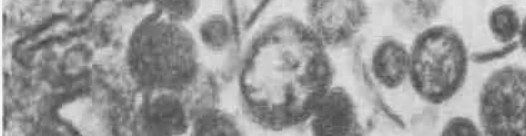

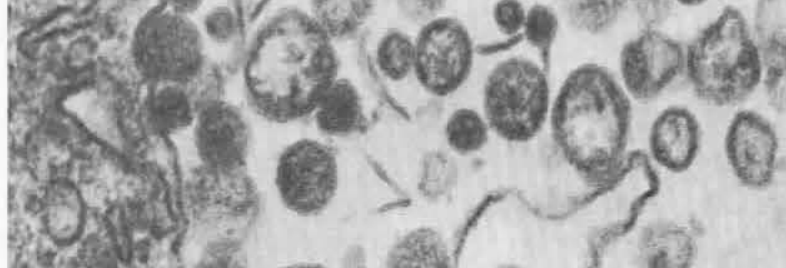

$13 x^{2}$.

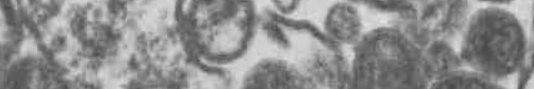

1)

$\cos 2$.

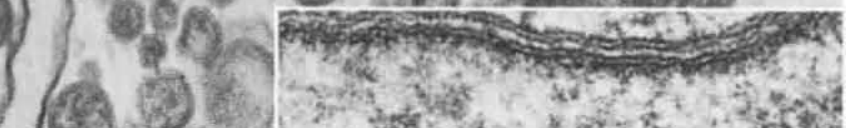

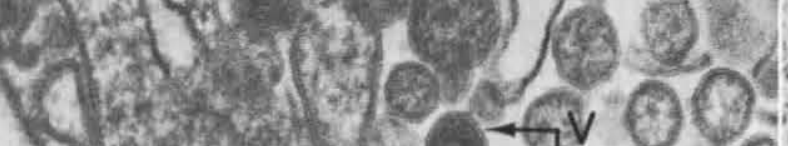

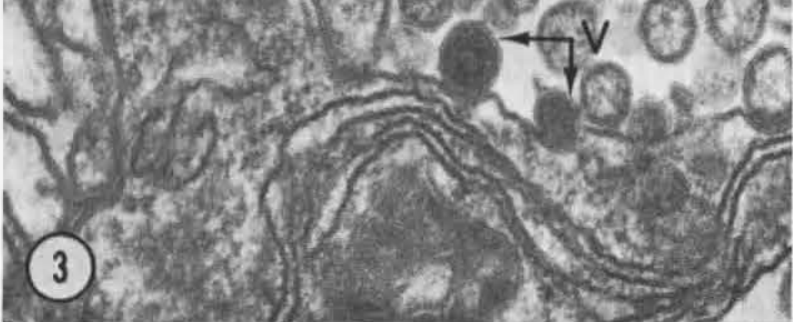

(i.

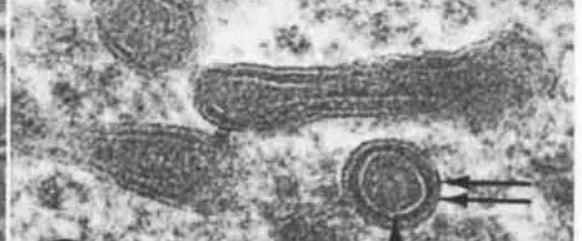

(4)

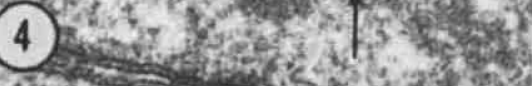




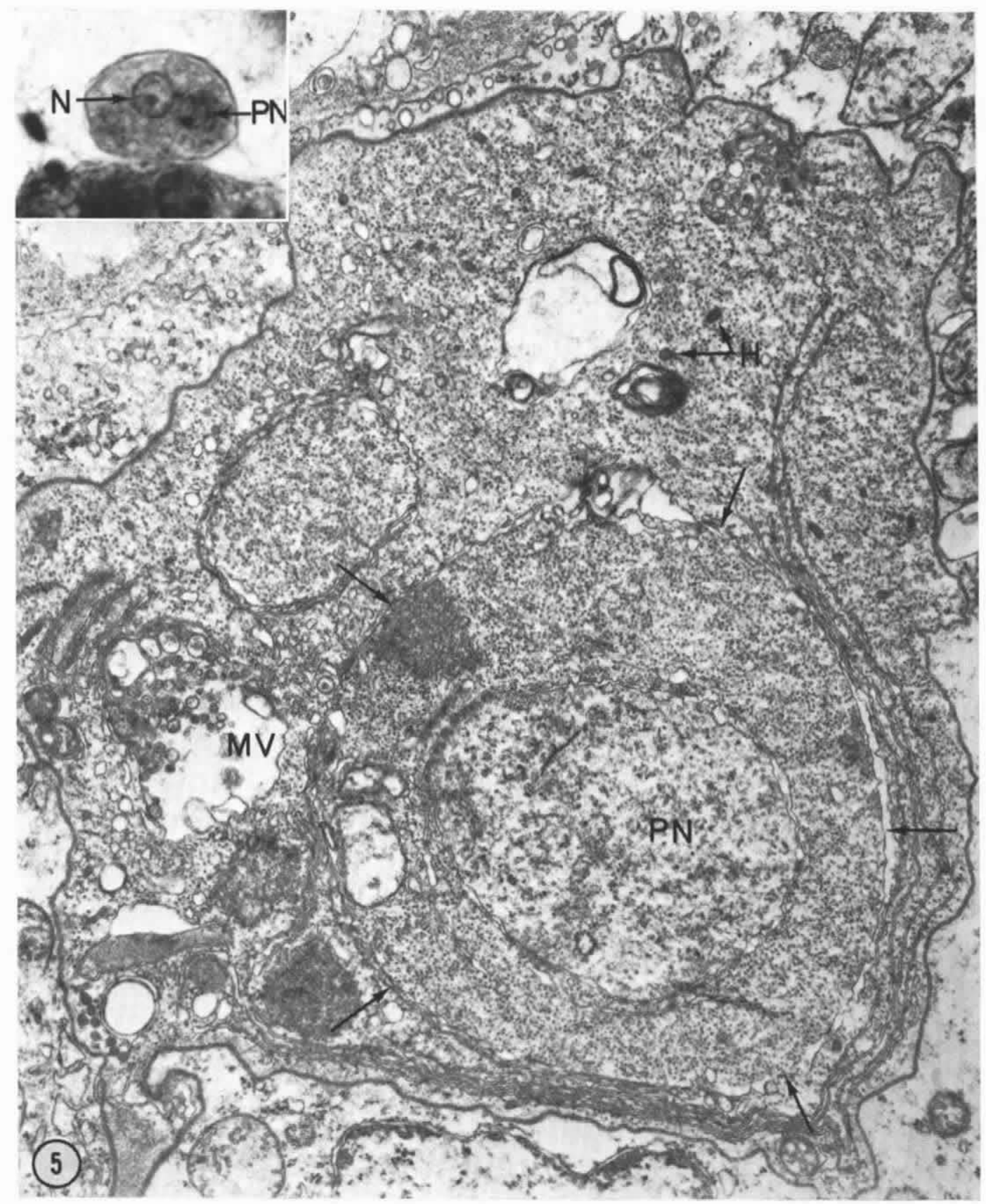

Figure 5. Plasmodium differentiating into sporangiosorus. A sporangial primordium (unlabeled arrows) has been cleaved from the plasmodial protoplasm. Note absence of haplosporosomes $(\mathrm{H})$ and multivesicular bodies (MV) from primordium. Primordium nucleus (PN), $\times 22,000$. Inset is light micrograph of a cell comparable to one in Fig. 5. Plasmodial nucleus (N); sporangial primordium nucleus (PN). $\times 1,500$. 


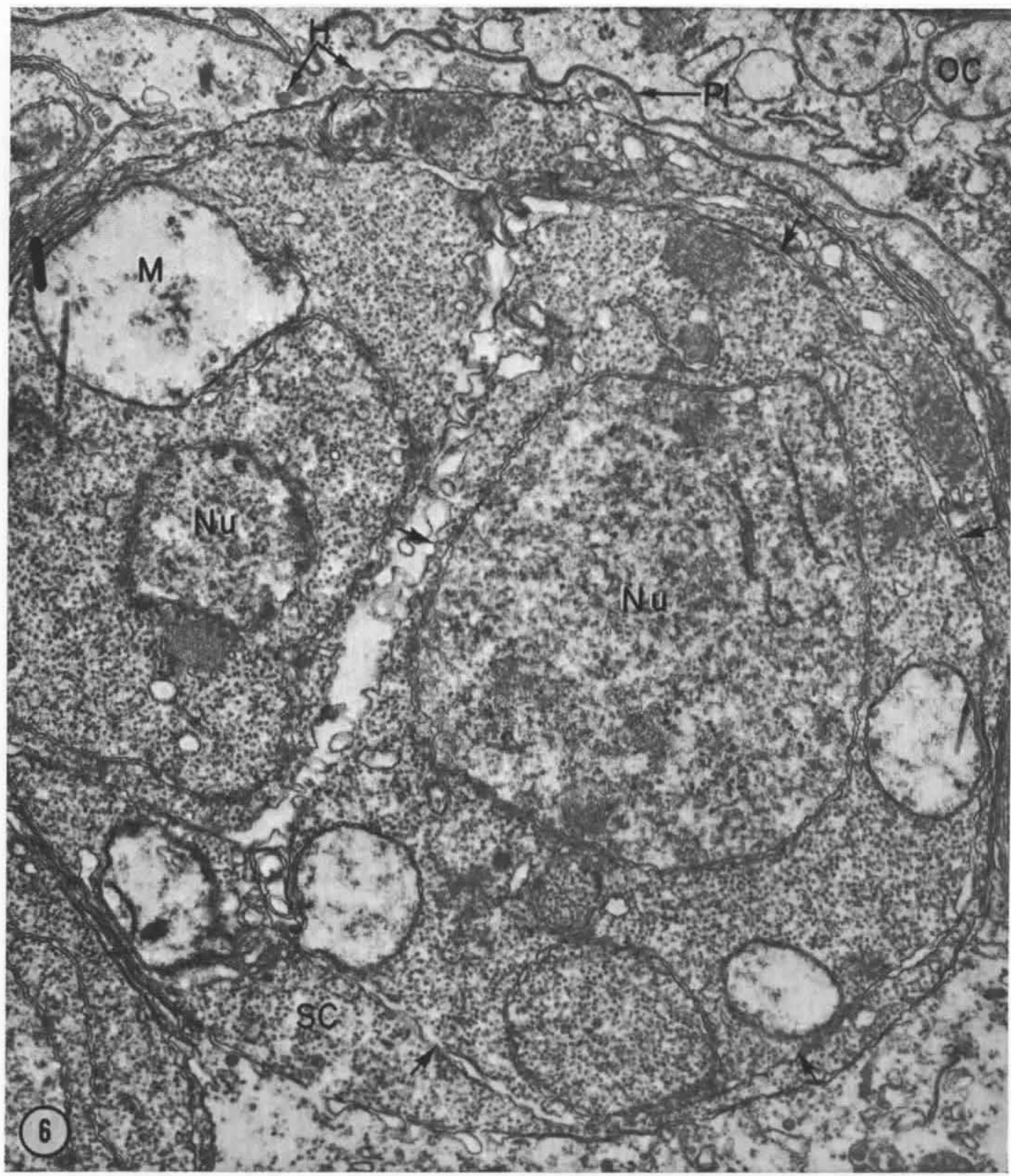

FIGURE 6. Sporangium with two spore primordia. Limits of one primordium are indicated by unlabeled arrows. Primordial nuclei ( Nu); mitochondrion (M); extraspore sporangial cytoplasm (SC); haplosporosomes in non-sporangial cytoplasm of sporangiosorus $(\mathrm{H})$; plasmalemma of sporangiosorus ( $\mathrm{Pl}$ ); oyster cell (OC). Sporangial wall not yet formed. $\times 26,000$.

\section{Description}

Earliest known presporulation stages are plasmodia in hepatopancreas lumens, in and between hepatopancreas cells, and in connective tissues surrounding hepatopancreas tubules. Plasmodial cytoplasm contains large multivesicular bodies and haplosporosomes. During sporulation plasmodium

enlarges and becomes a sporangiosorus. Eight to 16 sporangia form within sporangiosorus by internal cleavage, then each sporangium cleaves internally to form 2 (rarely, 3) spores. Spores spheroidal with greatest diameter 2.0 to $3.2 \mu \mathrm{m}$ in Davidson's - and formalin, acetic acid, alcohol (FAA)-fixed mate- 


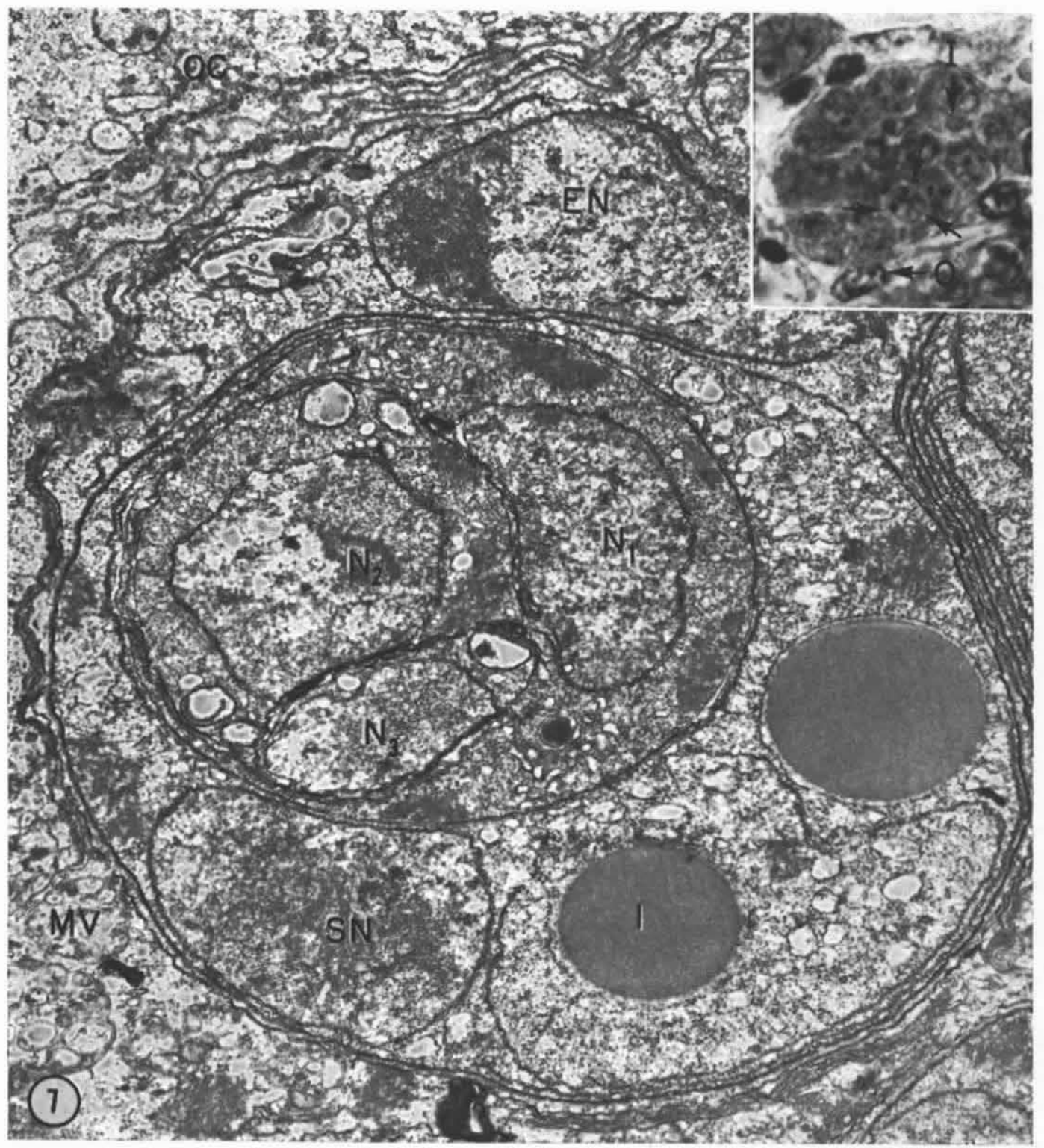

Frgure 7. Sporangium showing one immature spore in which the three uninucleate sporoplasms are visible. Nuclei of outermost $\left(\mathrm{N}_{1}\right)$, intermediate $\left(\mathrm{N}_{2}\right)$, and innermost $\left(\mathrm{N}_{3}\right)$ sporoplasms; extraspore sporangial nucleus (SN); extrasporangial nucleus (EN) of sporangiosorus; refringent inclusion (I); oyster cell (OC); multivesicular body $(\mathrm{MV})$ of extrasporangial cytoplasm. $\times 21,000$. Inset is light micrograph of sporangiosorus in same stage of development as the cell in Fig. 7. Unlabeled arrows indicate limits of one immature spore in which two nuclei are visible as dark dots. Refringent inclusion (I); oyster nucleus (O). $\times 1,500$.

rial $\left[\hat{x} \pm\left(s_{\tilde{z}}\right)\left(t_{. \omega}\right)=2.7 \pm 0.05 ; \mathrm{N}=30\right]$. Protoplasm of each spore consists of 3 uninucleate sporoplasms of graded sizes. Intermediate sporoplasm lies in a vacuole of the largest sporoplasm; the smallest sporoplasm in a vacuole of the intermediate one. Only outer sporoplasm con- tains haplosporosomes. Spore wall continuous without orifice or operculum. Extraspore protoplasm of sporangia degenerates leaving large numbers of spheroidal inclusion bodies 1.7 to 3.2 $\mu \mathrm{m}$ diameter. Spore cell wall enclosed by a myelin whorl, 140 to $420 \mathrm{~nm}$ thick. 


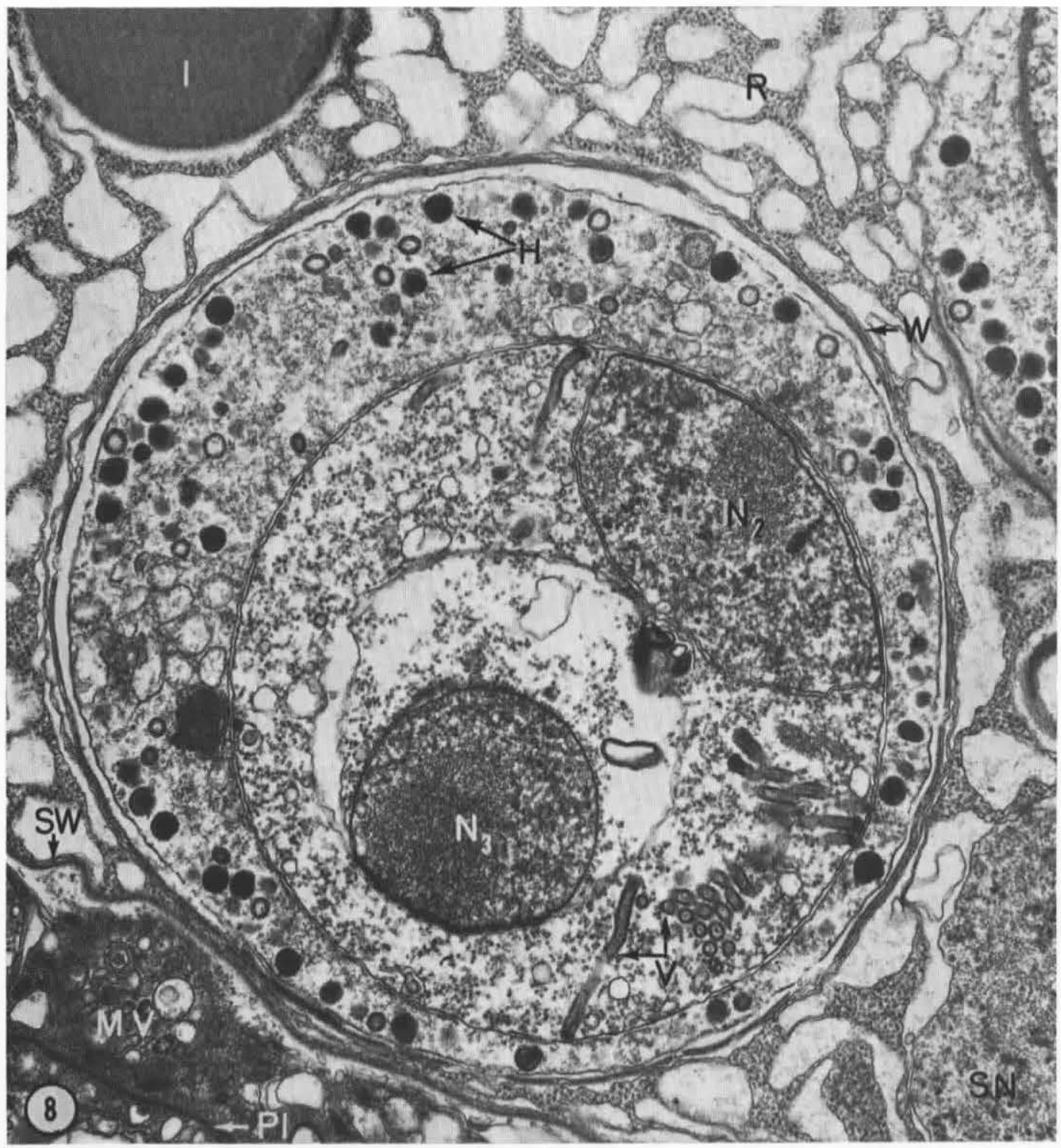

FIGUre 8. Nearly mature spore in which nuclei of intermediate $\left(\mathrm{N}_{2}\right)$ and innermost $\left(\mathrm{N}_{8}\right)$ sporoplasms are visible. Haplosporosomes (H) of outermost sporoplasm; double membrane-limited, flattened vesicles (V); spore wall (W); sporangial wall (SW); extraspore sporangial nucleus (SN); refringent inclusion (I); multivesicular body (MV) in extrasporangial cytoplasm; sporangiosorus plasmalemma (Pl). Note reticulated cytoplasm ( $\mathrm{R}$ ) of sporangial cytoplasm outside spores. $\times 30,000$.

\section{Biology}

Presporulation stages consist of plasmodia (Fig. 1) which contain scattered haplosporosomes, large multivesicular bodies (MV's), membrane-free endoplasmic reticulum (E.R.) cisternae, scattered ribosomes, and vesicular mitochondria which contain few cristae (Fig. 2). As noted by Perkins (1976) in studies of
$M$. refringens, it appears that haplosporosomes arise from vesicles inside the MV's which bud from the periphery of the MV, thus acquiring a delimiting, second membrane (Fig. 3). Free haplosporosomes vermiform or oblate, ranging from 146 to $603 \mathrm{~nm}$ long by 29 to $60 \mathrm{~nm}$ diameter $(\mathrm{N}=18)$ (Fig. 4). Striated inclu- 


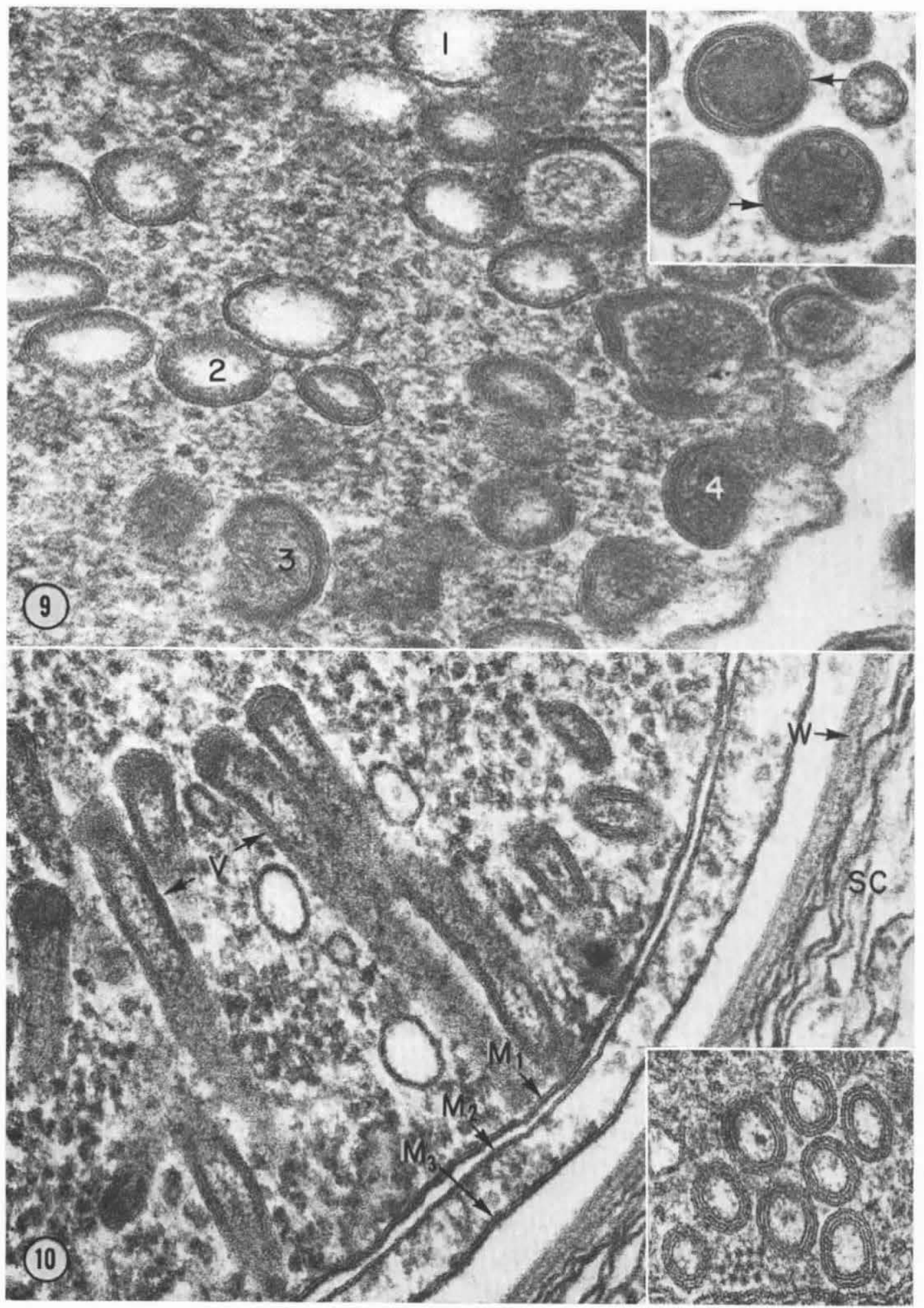




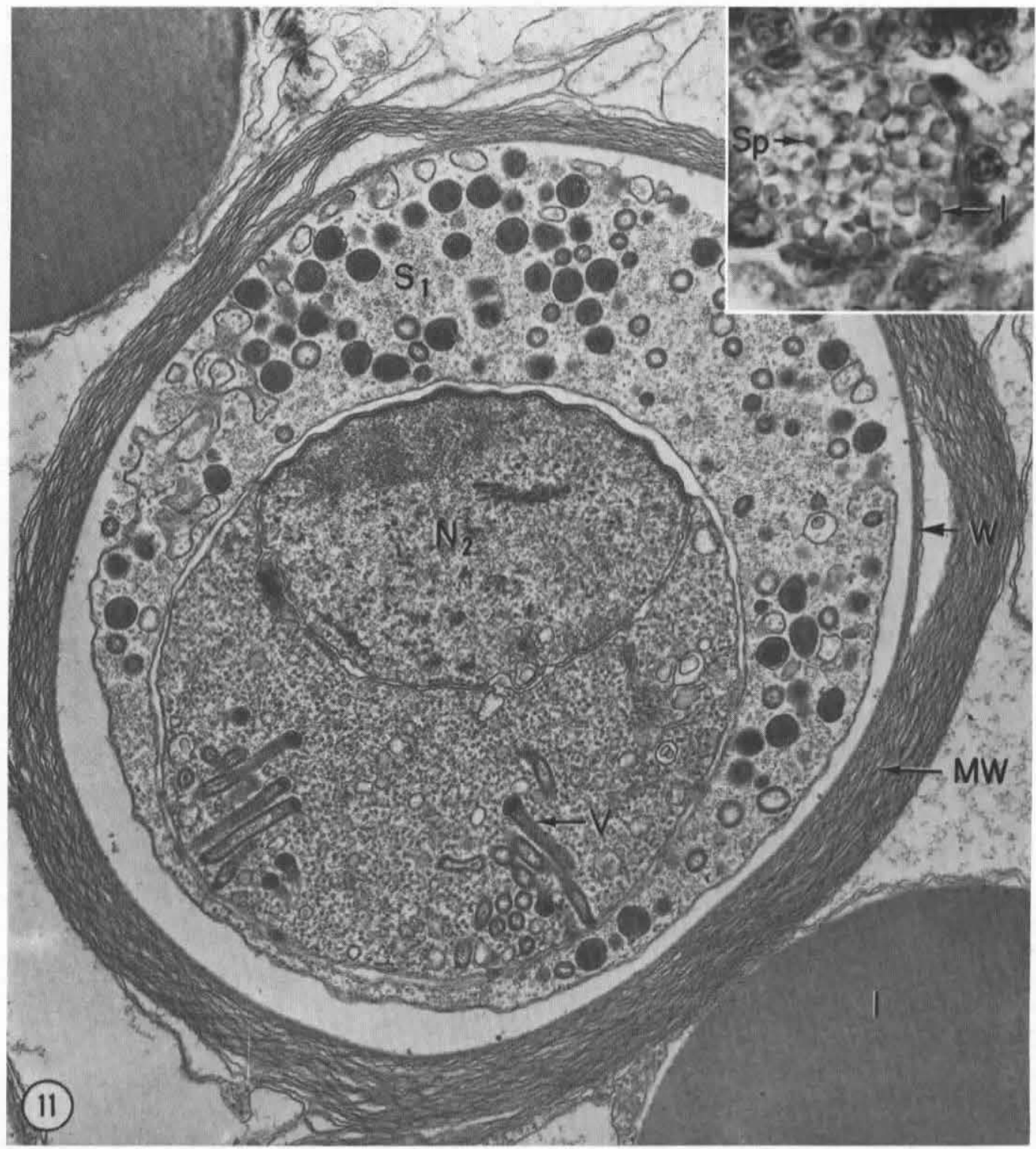

FIGURE 11. Mart. sydn. cont'd. Mature spore showing thick mantle of concentric membranes (MW) around wall $(\mathrm{W})$. Outermost sporoplasm $\left(\mathrm{S}_{1}\right)$; nucleus $\left(\mathrm{N}_{2}\right)$ of intermediate sporoplasm; flattened vesicle (V); refringent inclusion (I). $\times 132,000$. Inset is light micrograph of mature sporangiosorus showing high density of inclusion bodies (I). Spore (Sp). $\times 1,200$.

$\leftarrow$

Figures 9-10. Mart. sydn. cont'd. 9. Cytoplasm of outermost sporoplasm in nearly mature spore showing presumed developmental sequence $(1 \rightarrow 4)$ for haplosporosome formation. $\times 124,000$. Fully differentiated haplosporosomes (arrows) are shown in inset. Internal membrane is presumed to arise from collapsing and inpocketing of one side of vesicle membrane (between stages 2 and 3) followed by refusing of leading edges. $\times 136,000$. 10. Double-membrane limited, flattened vesicles $(V)$ of intermediate sporoplasm. Plasmalemma of intermediate sporoplasm $\left(\mathbf{M}_{1}\right)$; vacuole membrane of outermost sporoplasm $\left(\mathrm{M}_{2}\right)$; plasmalemma of outermost sporoplasm $\left(\mathrm{M}_{3}\right)$; wall $(\mathrm{W})$; degenerating extraspore sporangial cytoplasm (SC). $\times 130,000$. Inset contains cross-sectional views of flattened vesicles in which the pair of membranes can be distinguished. $\times 132,000$. 
sion bodies as found in plasmodia of M. refringens not present in $M$. sydneyi.

Sporulation is initiated by delimitation of internal, uninucleated segments of the plasmodial protoplast as a result of link-up of flattened vesicles aligned end-to-end (Fig. 5 ). The resulting pair of membranes in parallel orientation comprises the plasmalemma of a sporangial primordium and a vacuole membrane around the primordium. Haplosporosomes and MV's are not included in the cytoplasm of the primordium; only mitochondria, E. R. cisternae, large numbers of ribosomes, and a single nucleus. The ribosome density is higher than that observed in the surrounding, nonprimordial cytoplasm. Prior to sporangial primordia delimitation the plasmodia are 8 to $15 \mu \mathrm{m}$ long by 5 to $10 \mu \mathrm{m}$ wide $(\mathrm{N}=20)$ (measurements from histological sections of Davidson's-fixed material). From the time of sporangial primordia formation to completion of spore formation the size of the former plasmodium increases to 21 to 30 by 17 to $22 \mu \mathrm{m}(\mathrm{N}=25)$. After the appearance of sporangial primordia through spore maturation, the former plasmodia are termed sporangiosori.

Nuclear multiplication within the sporangial primordia followed by internal cleavage yields two (rarely, 3) uninucleated spore primordia and one or two nuclei in the remaining sporangial cytoplasm (Fig. 6). The latter degenerates toward the end of sporulation while the nuclei of spore primordia divide to yield three nuclei per spore (Fig. 7). Presumably there is one mitosis followed by mitosis in only one daughter nucleus since there is no evidence of a degenerate nucleus. Internal cleavage by vesicle link-up occurs to yield three uninucleate sporoplasms of graded sizes, one within a vacuole of the other. Refringent inclusions are formed in the extra-spore cytoplasm of the sporangium after spore primordium delimitation (Fig. 7).

The outermost sporoplasm is the only one which acquires haplosporosomes (Fig. 8). The organelles disappear from the plasmodia as they differentiate into sporangiosori then reappear during sporoplasm delimitation, apparently arising from vesicles scattered throughout the cytoplasm (Figs. 9, 10). Electron-dense material accumulates against the vacuole membrane (stages 1, 2; Fig. 9) then presumably an in- pocketing of the vesicle membrane yields the second, innermost membrane. Further accumulation of electron-dense material yields the mature form of the organelle (stages 3, 4; Fig. 9 ). Fully differentiated haplosporosomes are pleomorphic with most being oblate, spheroidal, or vermiform (Fig. 11). The longest axis is 148 to $288 \mathrm{~nm}$ with diameters of 57 to 163 $\mathrm{nm} \quad(\mathrm{N}=10)$. Other cytoplasmic organelles consist of vesicular mitochondria, vesicles, E.R., and membrane-free ribosomes. Lomasomelike extensions of the sporoplasm surface are found in one or two convoluted groupings of tubular cytoplasm. A wall ( 27 to $49 \mathrm{~nm}$ thick; $\mathrm{N}=17$ ) is formed around the sporoplasm involving the same mechanism as described for $M$. refringens (Perkins, 1976) (Figs. 8, 11).

The intermediate sporoplasm lies in a vacuole of the outermost sporoplasm and differs from the former in the lack of haplosporosomes and the presence of flattened vermiform vesicles 440 to $1160 \mathrm{~nm}$ long and 50 to $77 \mathrm{~nm}(\mathrm{~N}=15)$ diameter, which consist of two concentric membranes (Figs. 8, 10, 11). One end of the vermiform vesicles is enlarged and filled with electron-dense material within the innermost membrane. Whether these enlargements later develop into haplosporosomes was not determined. The other end of the flattened vesicles is closely opposed to the sporoplasm plasmalemma with electron-dense granular material bridging the gap between the two structures (Fig. 10). The innermost sporoplasm has the least organelle diversity, consisting of a single nucleus, one to three mitochondria, and membrane-free ribosomes (Fig. 8).

Extraspore, sporangial protoplasm becomes vacuolated after spore primordium formation (Fig. 8) then further degrades into groups of myelin whorls (Fig. 11). Each spore becomes covered by a whorl 140 to $420 \mathrm{~nm}$ thick $(\mathrm{N}=15)$. Large (1.7 to $3.2 \mu \mathrm{m}$ diameter; $\mathrm{N}=20$ ) spherical inclusion bodies accumulate in the sporangial cytoplasm during spore maturation, ultimately becoming so numerous as to mask the presence of spores in histological sections (Fig. 11 inset). A 16 to $27 \mathrm{~nm}$ $(\mathrm{N}=20)$ thick wall is formed around each sporangium about the time of spore primordium formation and persists through spore maturation (Fig. 8). 


\section{DISCUSSION}

M. sydneyi is considered to be a member of the genus because the mechanism of spore formation (i.e. plasmodial conversion via a series of internal cleavages into a sporangiosorus containing sporangia and spores) and spore structure is nearly identical to that of $M$. refringens, the only other member of the genus. The reader should refer to the paper on $M$. refringens (Perkins, 1976) for more complete descriptions of structures or developmental stages which are present in both species. The rationale for considering Marteilia spp. to be haplosporidan is also presented in that paper.

The Australian oyster pathogen is considered to be distinct from $M$. refringens because striated inclusion bodies are not formed in plasmodia, sporangiosori contain 8 to $16 \mathrm{spo-}$ rangia rather than about 8 , and sporangia contain two or, infrequently, three rather than four spores. The sizes of $M$. sydneyi and $M$. refringens mature sporangiosori are about the same as seen in histological sections, the former having a mean length (the longest axis) of 25 $\mu \mathrm{m}$ (range: 21 to $30 \mu \mathrm{m} ; \mathrm{N}=25$ ) and the latter having a mean length of 21 (range: 16 to $27 \mu \mathrm{m} ; \mathrm{N}=25)$. Spores are the same diameter $\left[\bar{x} \pm\left(s_{\bar{x}}\right)\left(t_{.05}\right)=2.7 \pm 0.05\right]$ for $M$. sydneyi vs. $2.6 \pm 0.05 \mu \mathrm{m}$ when measured from histological sections [material fixed in Davidson's or formalin, acetic acid, alcohol (FAA) fixatives]. "Diameters" were considered to be the longest axis since the spores are not always perfectly spherical. Student " $t$ " test indicates no significant difference in spore sizes within the $95 \%$ confidence limits.

Spores of $M$. sydneyi differ from those in the $O$. edulis pathogen in that a heavy layer of concentric membranes surrounds mature spores of the former whereas $M$. refringens spores generally lack such a covering, although loosely applied whorls have been observed around a few spores. Otherwise the spores appear to be identical.

The two species of Marteilia have a unique mechanism of spore formation. Internal cleavage of sporangia within plasmodia, followed by internal cleavage of spore primordia within sporangia, then internal cleavage of two sporoplasms within each spore primordium, yielding a total of three sporoplasms, is a mechanism not previously reported for Protozoa, fungi, or algae. The term endogenous budding from classical protozoology appears inappropriate in denoting internal cleavage because fine structure studies show that budding of protoplasm into an internal vacuole or cell surface depression does not occur. In Marteilia spp. primordia are delimited by vesicle fusion (Perkins, 1976), as has been described in the Phycomycetes (Gay and Greenwood, 1966) and some algae (Dodge, 1973).

In the senior author's paper (Perkins, 1976) on Marteilia refringens and in the present paper the botanical terms, sporangium and sporangiosorus, have been used; however, the usage is not intended to imply that species of Marteilia and other Haplosporea are considered to be fungi. They are clearly Protozoa. We consider the distinction between botanical and zoological terminology to be irrelevant at the phylogenetic level under consideration since we adhere to Whittaker's (1969) five kingdom classification in which most Protozoa and simple algae are grouped in the Kingdom Protista.

In the absence of strong evidence of sexuality, the classical botanical terms a) sporulation, b) sporangiosorus, c) sporangium, and d) spore have been tentatively selected because they most adequately denote asexual stages. The most appropriate and equivalent protozoological terms would be a) sporogony, b) sporocyst, e) spore, and d) sporozoite; however, sexuality would be implied. At present no haplosporidan life cycles have been elucidated thus it is not known whether spore formation is a meiotic or mitotic process. If the periodic nucleoplasmic structures described for $M$. refringens (Perkins, 1976) are polycomplexes, then meiosis is indicated. Sporogony and associated terminology would then be more appropriate than the terminology now being used. Protozoological terminology used to denote asexual development and cell types (i.e. schizogony, endopolyogeny, schizonts, and merozoites) is not adequate in descriptions of spore formation in Marteilia spp.

\section{ACKNOWLEDGMENTS}

The authors gratefully acknowledge the technical assistance of Mrs. Deborah DeBiasi, Miss Susan Fox, and Mrs. Patsy Berry. 


\section{LITERATURE CITED}

Alderman, D. 1974. Foreign diseases hazard British shellfish. New Scientist 63: 122-124.

DoDge, J. D. 1973. The fine structure of algal cells. Academic Press, New York, p. 159-166.

Gay, J. L. ANd A. D. Greenwood. 1966. Structural aspects of zoospore production in Saprolegnia ferax with particular reference to the cell and vacuolar membranes. In M. F. Madelin (ed.), The fungus spore. Butterworths, London, p. 95-110.

Gruzer, H., M. Comps, J. R. Bonami, F. Cousserans, J. L. Duthort, AND M. A. LePennec. 1974. Recherche sur l'agent de la maladie de la glande digestive de Ostrea edulis Linné. Science et Pêche, Bull Inst Pêches Marit 240: 7-30.

Mix, M. C. And V. Sprague. 1974. Occurrence of a haplosporidian in native oysters (Ostrea lurida) from Yaquina Bay and Alsea Bay, Oregon. J Invert Pathol 23: 252-254.

Perkins, F. O. 1976. Ultrastructure of sporulation in the European flat oyster pathogen, Marteilia refringens - taxonomic implications. J Protozool 23: 64-74.

WhitTAKER, R. H. 1969. New concepts of kingdoms of organisms. Science 163: 150-160.

Wolf, P. H. 1972. Occurrence of a haplosporidan in Sydney Rock oysters (Crassostrea commercialis) from Moreton Bay, Queensland, Australia. J Invert Pathol 19: 416-417.

\section{Suggestions to Prospective Authors}

In addition to general instructions inside the front cover of the Journal, the following hints have been printed from time to time:

On bibliographic style: see notice on p. 300 volume 61 , and follow models in the Journal.

On the Research Note: 47:396.

Hints on writing: 48: 176, 51: 553, 52: 232, $406, \mathbf{5 4}: 535, \mathbf{5 5}: 354,688, \mathbf{5 8}: \mathbf{7 2 2 , 5 9 :} 276$.

Preparation of drawings and plates: 52: 1024, 53: $660,54: 50,358,56: 264,58: 554$.

Authors are now charged at the rate of $\$ 40.00$ per page for all pages over 4. Excessive corrections in proof will be charged to the author.

All copy must be double spaced, including bibliographies, legends to plates, etc., and the master copy must be a ribbon copy on bond paper. Legends must be typed on a separate sheet and not tacked on to the illustrations. All illustrations must be numbered on the back for identification. Composite halftone plates should be mounted with at least an inch margin to protect edges of the prints, and for editorial marking.

Plates must be designed for either single column ( 16 picas), or double column ( 33 picas) width, as reproduced. Odd sizes are not permitted. Plates must be rectangular. Steps in margins are not permitted. Individual prints must be accurately squared and butted, no white showing. The engraver will cut a fine hairline of separation between the figures. It is advantageous, where convenient, to have the plate as printed a little shorter than page length, so that the legend can be fitted below. This makes it easier to fit the article into the dummy and may result in earlier publication.

The author should make it clear whether magnifications of plates, as given, are for the plate as it will appear in the Journal, or must be recalculated for the intended reduction. Where plates have been designed for special treatment, in conference with the editor, such as bleeding to edge of page, this must be clearly marked by the author on margin or back of plate. Otherwise such arrangements are likely to be forgotten by the time the manuscript goes to the printer. It is foolish to waste words trying to describe features best seen in the illustrations. There is nothing wrong with stating "as figured."

Excessive bibliographies are to be avoided, particularly references to procedures which have by now become standard (such as EM techniques). Twenty five entries should be a maximum. Recently some research notes have been submitted with as many as five authors! This would be excessive for a full blown article, and on a research note approaches the ridiculous.

When in doubt, authors should study recent numbers of the Journal for handling of similar material. We cannot permit wide departures from established Journal style since this greatly complicates the work of the editor and printer. Where most measurements are less than $1 \mathrm{~mm}$, values should be given "in microns unless otherwise stated."

The editor's office cannot answer trivial inquiries unless a self-addressed stamped envelope or postcard is included.

The EDrTon 